\title{
International Trade Integration and Business Cycle Synchronization
}

Luciana Juvenal, Economist

$\mathrm{T}$ rade and international capital flows have grown rapidly in recent years. The sum of U.S. exports to the rest of the world (ROW) plus imports from the ROW, as a percentage of gross domestic product (GDP), increased by 50 percent from 1974 to $2007 .{ }^{1}$ Cross-country financial holdings also increased substantially during this period. U.S. international portfolio investments increased from 2 percent to 29 percent of U.S. capital stock from 1974 to 2007; foreign asset holdings in the United States similarly increased.

Although trade has grown and investors have diversified their international asset holdings, U.S. output and consumption commove less with those in the ROW. In particular, the correlation between U.S. real output and that of the ROW sharply declined, while the correlation between U.S. real consumption and that of the ROW declined much more modestly. The U.S.-ROW GDP correlation declined from 0.71 to 0.26 between 1974 and 1985 and 1986 and 2007, while the U.S.-ROW consumption correlation declined from 0.37 to 0.27 across the same periods (see the table). ${ }^{2}$

The changes in international trade and finance are linked to the changes in business cycle correlations. ${ }^{3}$ Because trade integration tends to increase specialization in production, it may reduce output correlation across countries when asymmetric industry-specific shocks occur. For example, a positive shock to production in the auto industry will increase production in carproducing countries but reduce it in others. On the other hand, greater international asset diversification increases the ability of countries to share risks, thereby insuring each other against declines in consumption (see the chart). For example, when the U.S. stock market declines, U.S. consumers can offset some of their losses

\section{The changes in international trade and finance are linked to the changes in business cycle correlations.}

\section{Real Output and Real Consumption Correlations}

\begin{tabular}{lcc} 
Period & $\mathbf{Y}_{\text {US }}, \mathbf{Y}_{\text {ROW }}$ & $\mathbf{C}_{\text {US }}, C_{\text {ROW }}$ \\
\hline $1974-2007$ & 0.52 & 0.33 \\
$1974-1985$ & 0.71 & 0.37 \\
$1986-2007$ & 0.26 & 0.27
\end{tabular}

NOTE: The table shows the correlations calculated on filtered quarterly series taken from the Organisation for Economic Co-operation and Development. The series are expressed at $\mathbf{2 0 0 0}$ national currency constant prices and converted into U.S. dollars using 2000 purchasing power parity exchange rates.

\section{U.S. Assets, Liabilities, and Trade}

Percent of U.S. Capital Stock

Percent of U.S. GDP

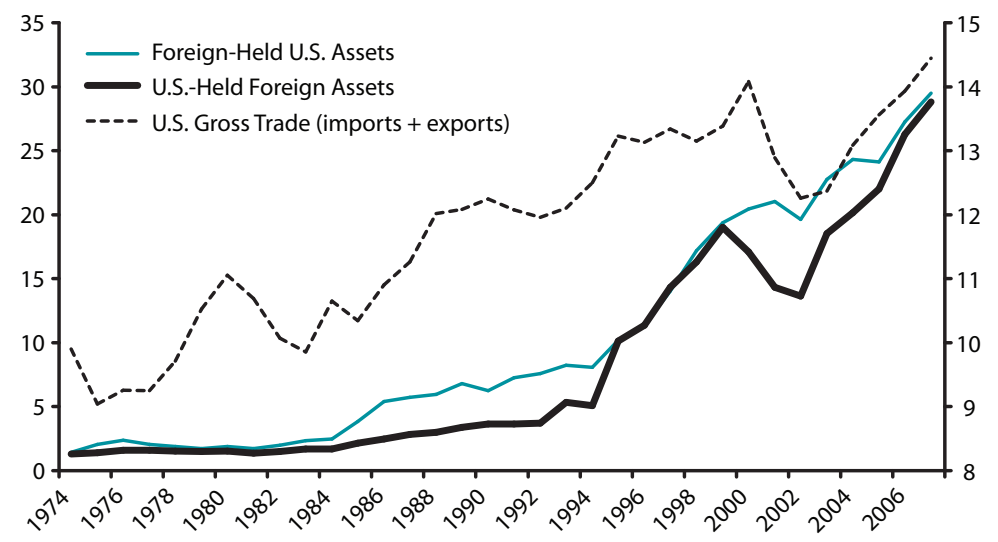

NOTE: Asset holdings are measured on the left axis, and gross trade is measured on the right axis. SOURCE: Bureau of Economic Analysis and International Monetary Fund. 
with asset holdings in other countries. As a consequence, people can continue to consume at nearly normal rates, even during a recession. Thus, consumption correlations may decrease by less than output correlations or even increase.
${ }^{1}$ The ROW series are an aggregate of Canada, Japan, and Europe. Europe includes the following 15 countries: Austria, Belgium, Denmark, Finland, France, Germany, Greece, Ireland, Italy, Norway, the Netherlands, Portugal, Spain, Sweden, and the United Kingdom.

2 The selection of 1985 as a breakpoint is related to the moderation of the U.S. business cycle.

${ }^{3}$ Juvenal, Luciana and Santos Monteiro, Paulo. "Trade Integration and Financial Globalization.” Unpublished manuscript, Federal Reserve Bank of St. Louis, 2009. 